\title{
Accumulation of Innate Amyloid Beta Peptide in Glioblastoma Tumors
}

\author{
Lilia Y. Kucheryavykh ${ }^{1}{ }^{1}$, Jescelica Ortiz-Rivera ${ }^{1}$, Yuriy V. Kucheryavykh ${ }^{1}$, \\ Astrid Zayas-Santiago ${ }^{2}$, Amanda Diaz-Garcia ${ }^{2}$ and Mikhail Y. Inyushin ${ }^{2, *} \mathbb{C}$
}

1 Department of Biochemistry, School of Medicine, Universidad Central del Caribe, PO Box 60327, Bayamon, PR 00960-6032, USA; lilia.kucheryavykh@uccaribe.edu (L.Y.K.); 416jortiz@uccaribe.edu (J.O.-R.); yuriy.kucheryavykh@uccaribe.edu (Y.V.K.)

2 Department of Physiology, School of Medicine, Universidad Central del Caribe, PO Box 60327, Bayamon, PR 00960-6032, USA; astrid.zayas@uccaribe.edu (A.Z.-S.); 417adiaz@uccaribe.edu (A.D.-G.)

* Correspondence: mikhail.inyushin@uccaribe.edu; Tel.: +1-787-667-6469

Received: 8 April 2019; Accepted: 15 May 2019; Published: 20 May 2019

check for updates

\begin{abstract}
Immunostaining with specific antibodies has shown that innate amyloid beta $(\mathrm{A} \beta)$ is accumulated naturally in glioma tumors and nearby blood vessels in a mouse model of glioma. In immunofluorescence images, $\mathrm{A} \beta$ peptide coincides with glioma cells, and enzyme-linked immunosorbent assay (ELISA) have shown that $\mathrm{A} \beta$ peptide is enriched in the membrane protein fraction of tumor cells. ELISAs have also confirmed that the $A \beta(1-40)$ peptide is enriched in glioma tumor areas relative to healthy brain areas. Thioflavin staining revealed that at least some amyloid is present in glioma tumors in aggregated forms. We may suggest that the presence of aggregated amyloid in glioma tumors together with the presence of $A \beta$ immunofluorescence coinciding with glioma cells and the nearby vasculature imply that the source of $A \beta$ peptides in glioma can be systemic $A \beta$ from blood vessels, but this question remains unresolved and needs additional studies.
\end{abstract}

Keywords: amyloid; A $\beta$ peptide; glioma; platelets

\section{Introduction}

As Alzheimer's disease (AD) affects mostly the elderly population [1], gliablastoma (GBM) is the most common primary malignant brain tumor in older people [2]. Recently, statistically independent cohort studies have found an inverse association between cancers in general and AD [3-5]. Specifically, most patients with AD are protected from lung cancers [3], and, vice versa, cancer survivors have a lower risk of AD [6]. However, there is a significant positive correlation between the AD mortality rate and the malignant brain tumor mortality rate $[4,7,8]$. These correlations suggest that there are common factors in these diseases. Mitochondrial metabolism, in general, and the p53, Pin1, and Wnt cellular signaling pathways, in particular, were proposed as possible linkages in this cancer-AD relationship [9,10]. Interestingly, chemotherapy [6] and radiotherapy [9] also affected this correlation.

On the other hand, the buildup of amyloid precursor protein (APP), the precursor of the AD hallmark amyloid beta $(\mathrm{A} \beta)$ peptides, have now been found in pancreatic and breast cancer tumors and the corresponding metastatic lymph nodes [11,12]. Proteolytic cleavage of APP by the $\alpha$-secretase pathway mediates proliferation and migration in breast cancer, while other pathways were not studied [13]. It was also discovered that plasma levels of $\mathrm{A} \beta$ peptides in esophageal cancer, colorectal cancer, hepatic cancer, and lung cancer patients were significantly higher than in normal controls [14]. The question arises, what is the source of these $\mathrm{A} \beta$ peptides? Moreover, what is their role?

$\mathrm{A} \beta$ peptides can be generated by glioma cells themselves. It was shown that glioma cells in culture produce the $4-\mathrm{kDa} A \beta$ peptide, which co-migrates with synthetic $\mathrm{A} \beta(1-40)$ (also known as $\mathrm{A} \beta 40$ ) and 
is specifically recognized by antibodies raised against terminal domains of the $\mathrm{A} \beta$ peptide, and releases them into the medium [15]. The role of $A \beta$ peptides in glioma development was investigated in another study [16]. It was reported that full-length $A \beta 40$ is a dose-dependent inhibitor of angiogenesis and suppresses human U87 glioblastoma subcutaneous xenografts in nude mice. A small peptide sequence of $A \beta, A \beta(11-20)$, was found to be a potent, anti-angiogenic molecule. Systemic delivery of this peptide leads to reductions in glioma proliferation, angiogenesis, and invasiveness [16]. Furthermore, parallel experiments in transgenic mice overexpressing $A \beta 40$ also showed reductions in glioma growth, invasion, and angiogenesis [16-18].

However, besides glioma itself, there is another systemic source of $A \beta$ peptide production in the body $[19,20]$. Recently, we showed that platelets produce a massive release of $A \beta$ after thrombosis in the brain and skin and that this release is concentrated near blood vessels [21,22]. It has been shown that platelets are hyperactivated in cancer patients and form cancer cell-induced aggregates and micro-thrombi in the vasculature near tumors (reviewed in [23]). A high platelet count is associated with poor survival in a large variety of cancers, while thrombocytopenia or antiplatelet drugs can reduce the short-term risk of cancer, cancer mortality, and metastasis (reviewed in [24]). Platelets affect glioma cells by releasing platelet-derived growth factor (PDGF) [25]. May platelet-generated A $\beta$ also diffuse to glioma cells and accumulate inside these brain tumors?

In our study, we chose specific antibodies against $A \beta$ peptides with low reactivity for the precursor APP to see whether $A \beta$ immunoreactivity is present in glioma tumors and nearby blood vessels in mice. We used an enzyme-linked immunosorbent assay (ELISA) to study A $\beta 40$ content in tumor and "healthy" brain area, while also assessing A $\beta 40$ content in the membrane and cytoplasmic fractions of glioma cells. The presence of aggregated forms of amyloid inside glioma tumors was evaluated as well.

\section{Results}

2.1. Immunoreactivity against A Peptides Is Present in Glioma Cells in Primary and Secondary Tumors as Well as in Blood Vessels and Erythrocytes in the Near Vicinity, Indicating that the A $\beta$ Level Is Elevated in the Tumor Zone

After glioma implantation into mouse brains using standard methods established in our laboratory $[26,27]$ we allowed 16 days of tumor growth. We then prepared brain slices containing tumors within nearby tissue. Immunostaining with polyclonal (Figure $1 \mathrm{~A}, \mathrm{~B}$, green) antibody against $\mathrm{A} \beta$ showed that these peptides are present in glioma cells (white arrows), in nearby broken blood vessels, and in escaped erythrocytes. In addition, astrocytes are marked by red fluorescence (anti-Glial Fibrillary Acidic Protein (anti-GFAP)), and the nuclei are marked blue (4',6-diamidino-2-phenylindole (DAPI) staining). The same images (Figure 1A,B) are presented as moving confocal images (Figure S1A,B) so that blood vessel details and their relation to glioma cells are more discernable. Inside blood vessel segments marked by $A \beta$ green immunofluorescence, erythrocytes were also specifically marked by $A \beta$ (Figure 1A,B, see also Figure S1A,B) as well as erythrocytes diffused locally near broken blood vessels (Figure $\mathrm{S1A}, \mathrm{B}$ ), as blood vessels near the tumor are usually ruptured [28]. As was shown previously, $A \beta$ peptide in blood plasma binds to practically all erythrocytes and may be a marker for AD [29]. Also, the addition of synthetic $A \beta$ specifically marks erythrocyte membranes [30]. We want to stress once again that $A \beta$ immunofluorescence is present only in blood vessel segments near the glioma tumor and in the tumor itself (Figure 1A,B and Figure S1A,B). Therefore, only the glioma cells in the tumor and nearby blood vessels containing erythrocytes and within the distance $0-200 \mu \mathrm{m}$ from the ruptured blood vessel are fluorescent. 

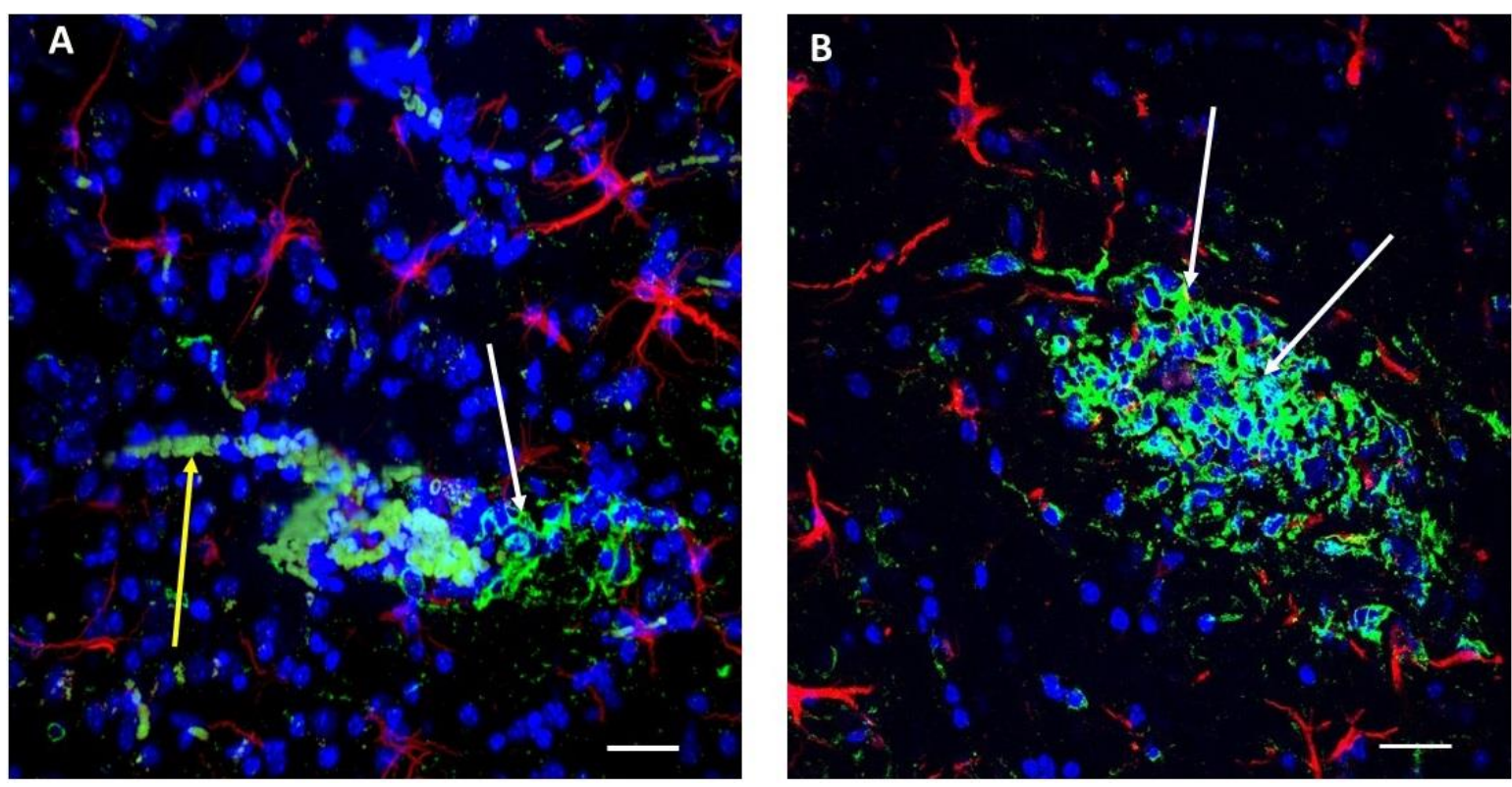

Figure 1. A $\beta$ peptide immunoreactivity (green) in glioma cells and in nearby blood vessels. (A) A small glioma tumor near a broken blood vessel. A $\beta$ peptide immunoreactivity (green) visible in glioma cells (white arrow) and in blood vessels. Erythrocytes released from the broken vessel are also marked with $A \beta$-related immunofluorescence (yellow arrow). (B) A larger glioma tumor in which a broken blood vessel passes through the tumor (more clearly visible in the 3D image of this tumor shown in Figure S1B), and white arrows indicate glioma cells marked by green immunofluorescence representing $A \beta$ peptide. For $\mathbf{A}$ and $\mathbf{B}$, astrocytes are indicated by immunoreactivity to GFAP (red) and cell nuclei by DAPI staining (blue). Scale bar, $20 \mu \mathrm{m}$. (See also supplemental confocal 3D images of the same tumors in Figure S1A,B, respectively).

We also made ELISA measurements of mouse $A \beta 40$ peptide in the brain sample tissue containing the main tumor versus the "healthy" control from the corresponding cortical zone in the other hemisphere from the same animal 16 days after glioma implantation. Similar amounts of the homogenate were taken for analysis. It was found that the relative amount of $\mathrm{A} \beta 40$ in the glioma tissue was $142 \pm 9 \%$ larger and statistically different $(p<0.001 ; t=4.714 ; \mathrm{d} f=4 ; n=3)$ from "healthy" tissue (Figure 2A).

In these experiments, we found that glioma cells exhibit specific $A \beta$ immunofluorescence that clearly marks these cells, but the question arises whether it is inside the cells or somehow attached to the external membrane.

\subsection{Aß40 Is Concentrated in the Membrane Cell Fraction in Glioma Tumor Tissue}

To determine more precisely there $A \beta$ is distributed, we separated the cytoplasmic and membrane fractions of proteins from glioma cells from the main tumor extracted from the brain of animals 16 days after implantation. Before processing, blood cells were eliminated from the tumor tissue samples using the Percoll purification method. Membrane and cytoplasmic proteins were isolated, and the total protein content was determined using the Bradford spectrophotometric method to establish a reference point for measuring the amount of $A \beta$ in each fraction. Using ELISA, it was found that the relative amount of $\mathrm{A} \beta 40$ in the membrane fraction is significantly greater $(170 \pm 4 \%, p<0.001, t=16.23, \mathrm{~d} f=4$, $n=3$ ) than in the cytoplasmic fraction (Figure 2B). 


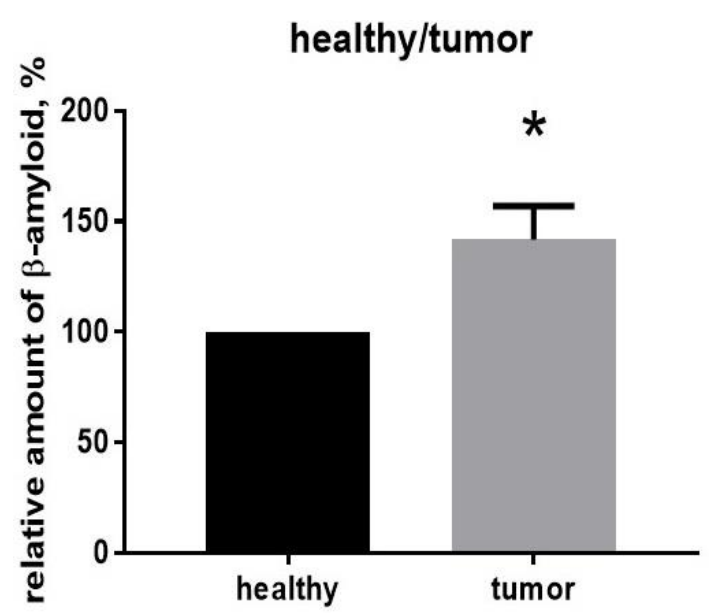

(A)

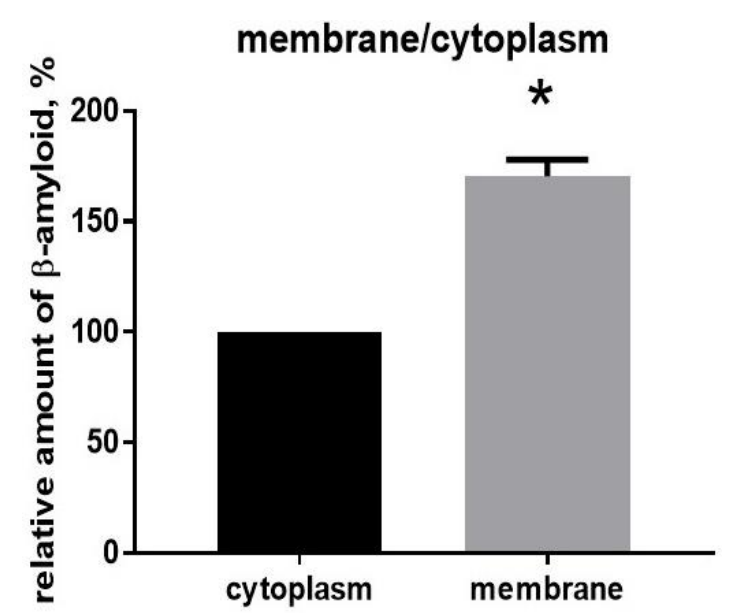

(B)

Figure 2. (A) The relative amount of $A \beta 40$ in the glioma tissue is elevated. (B) A $\beta 40$ in glioma tumor tissue is concentrated in the cell membrane fraction.

\subsection{Glioma Tumor Tissue Contains Aggregated Amyloid}

To determine whether glioma tumors have aggregated forms of $A \beta$ with cross- $\beta$ architecture, we used standard thioflavin $\mathrm{T}$ and thioflavin $\mathrm{S}$ staining of brain slices with glioma from animals with implanted glioma cells. It was previously demonstrated that both thioflavin $T$ and thioflavin $S$ fluorescence originates mainly from dye bound to aggregated forms of amyloids with cross- $\beta$-pleated sheet structure, and gives a distinct increase (and a spectral shift in the case of thioflavin T) in fluorescence emission after binding [31,32]. We used IP injection of thioflavin $\mathrm{T}$, while slices containing tumors were additionally stained with thioflavin S. Both dyes specifically marked glioma tumors (Figure 3), in which staining (green for thioflavin $\mathrm{T}$ and red for thioflavin $\mathrm{S}$ ) is obvious only inside the tumor body, while the nearby normal tissue remained unstained.

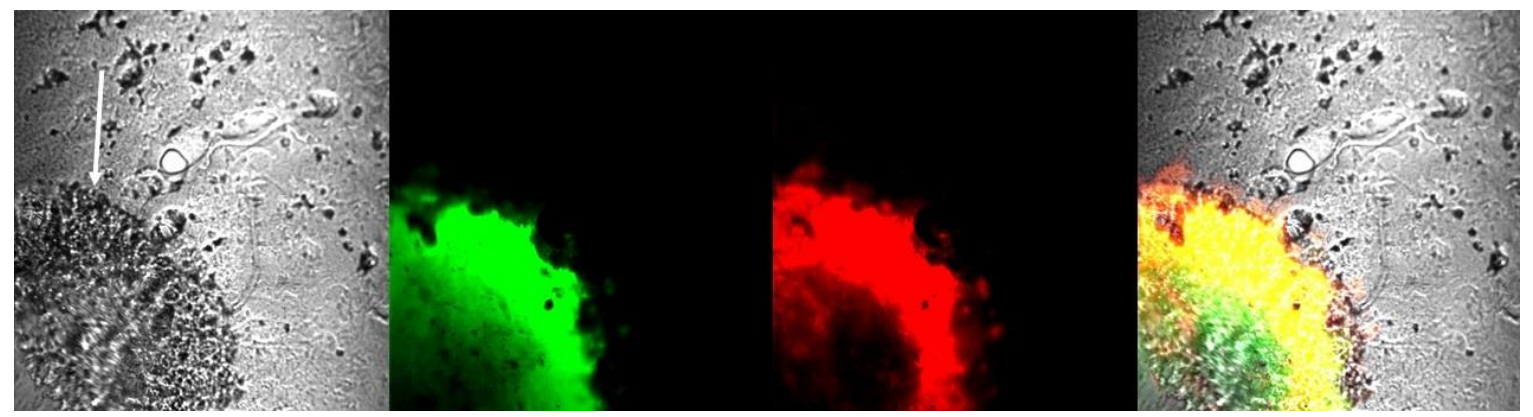

Figure 3. Aggregated amyloid visualized by staining with thioflavin T (green) and thioflavin S (red) inside the glioma tumor body. The white arrow shows the glioma tumor body visible in the brain slice.

\section{Discussion}

Here we report that antibodies against A $\beta$ with relatively low reactivity against APP [33] show $A \beta$ immunostaining in glioma cells and nearby blood vessels in mice (Figure 1). Using ELISA, we also report that $A \beta 40$ levels are significantly increased in glioma (Figure 2). Glioma tissue from one brain hemisphere contains about two-fold more $A \beta$ than a similar amount of tissue from the "mirror" hemisphere, with $A \beta$ concentrated in the membrane fraction. The question arises whether $A \beta$ is coming from the systemic source-from the blood, and is marking the glioma cell membrane-or is synthetized by glioma cells themselves.

Previous studies support the possibility of systemic source for this $A \beta$. The results indicating increased $A \beta$ content in blood plasma for different types of cancer have already been reported [14]. 
Systemic $A \beta$ is generated in large quantities by blood platelets in broken vessels, as we have shown for the thrombotic process [21,22]. Here, broken blood vessels marked by extensive $A \beta$ fluorescence can be seen near tumors in our experiments (Figure 1A,B and Figure S1A,B). It has been shown previously that platelets are hyperactivated in cancer patients and form cancer cell-induced aggregates and micro-thrombi in vasculature near tumors (reviewed in [23]), thus suggesting that the source of $A \beta$ that we have found for the clotting process may also be present here. It seems possible that $A \beta$ released from clots can migrate and somehow mark only glioma cells (Figure 1A,B), but this raises new questions about why $\mathrm{A} \beta$ marks glioma cells so specifically.

To bind specifically, $A \beta$ must be recognized by a specific receptor on the external membrane of the glioma cell. A known specific A $\beta$ receptor, such as the PrPC-mGluR5 complex, is associated with proline-rich tyrosine kinase 2 (Pyk2 or PTK2B) [34,35]. This receptor localizes to postsynaptic sites in the brain, but is also overexpressed in all glioblastoma cells, where it controls cell migration $[27,36]$. A $\beta$ is a known inhibitor of Pyk2 [35]. Thus, its release by platelets may be a part of the intrinsic immunity that is directed against cancerous gliomas. Another suspected molecule related to A $\beta$ binding is PI3K (phosphatidylinositol [PI] type 3 receptor tyrosine kinase). This kinase and its signaling network is also present and hyperactivated in a majority of glioblastoma cells, where it controls membrane microdynamics and cell cycling $[37,38]$. Its $A \beta$ receptor is unknown, but it complexes with PI3K and most probably is situated on the external membrane $[39,40]$. It is known that A $\beta$ inhibits PI3K activity as well [41]. We speculate that in this case, $A \beta$ peptides generated by platelets also play a role in the intrinsic immunity directed against cancerous gliomas.

In addition, $A \beta$ may bind to the advanced glycation end products (RAGE) receptor. It is known that this receptor is the binding site for $A \beta$ peptides [42] thus mediating $A \beta$ transport through the blood-brain barrier [43]. Very same RAGE receptor regulates the tumor environment and tumor cell migration, is part of the important microglial activation mechanism and is overexpressed in tumors [44].

On the other hand, it was shown that glioma cells in culture produce $A \beta$ peptides that comigrate with synthetic $A \beta 40$ and are specifically recognized by antibodies raised against the terminal domains of the $A \beta$ peptide and released by these cells into the medium [15]. However, cultured and in vivo astrocytes also produce $A \beta$ peptides is similar amounts [45-47] and astrocytes were not marked by $A \beta$ immunofluorescence in our experiments, probably because these peptides is present in/near the astrocytes in amounts that can be neglected compared with the glioma tumor cells that we have studied here. While derived from the same cell type, glioma cells are clearly marked by A $\beta$ immunofluorescence in our experiments (Figure 1).

It is clear that the question of whether the source of $A \beta$ is inside the glioma cell itself or is a systemic source from blood vessels should be investigated further. Anyway, all our results from these experiments taken together as well as our previous experience with $A \beta$ peptides released during platelet accumulation and aggregation in thrombotic blood vessels [21,22] lead us to the conclusion that most probably $\mathrm{A} \beta$ peptides are generated by platelets and somehow bind almost exclusively to glioma cells.

An additional issue is the accuracy of $\mathrm{A} \beta 40$ concentrations measurements in brain tissue. In our study of $A \beta 40$ concentrations in tissue, we used relative values, indicating the percentage change from initial values, as the most accurate. It was shown previously that the Invitrogen A $\beta 40$ ELISA Kit is very specific to murine $A \beta 40$, but the data are very sensitive to "noise" (such as the presence of other proteins and lipids), and absolute values can deviate 40-50\% [48]. Also, ELISA data may vary considerably, with a variety of collection and storage protocols [49]. Measurement of A $\beta$ by ELISA reveals mainly free peptides, while a significant amount of $A \beta$ peptide remains bound to proteins, lipoproteins, and cell membranes [50].

Our experiments also indicate that there is some thioflavin-positive amyloid inside glioma tumors (Figure 3). While we have shown that $\mathrm{A} \beta$ peptides are definitely present in tumor and may constitute a predominant part of this glioma amyloid, the specific type of aggregated amyloid found inside the borders of glioma tumors is unknown. To our opinion, this amyloid is most probably mixed amyloid, 
as was found for AD [51]. Protein aggregation is sequence specific, not favoring self-assembly over cross-seeding with nonhomologous sequences [52]. However, proteins with aggregation-prone regions may aggregate with each other at elevated concentrations, forming a mixed misfolded amyloid [53]. In this case, one aggregated protein can work as a "seed" for aggregation of other protein types. Previously, different amyloids were found in a variety of tumors. Different carcinomas have amyloid stroma [54,55], and odontogenic tumors are positive for thioflavin $\mathrm{T}$ and Congo Red staining and are also immunopositive for the enamel matrix protein ameloblastin [56-58]. Similarly, amyloid was reported in breast cancer tumors but was determined to be a localized amyloid light chain (AL) type (primary amyloidosis caused by ImG light-chain $\beta$-sheeting) [59,60]. Localized AL type amyloidosis was also found in myeloma (plasma cell) tumors as well as in kidneys and early-stage non-small-cell lung adenocarcinomas [61]. If the content of amyloid in glioma tumors is mixed, it must be further studied, because tumor-related amyloid could be a new target for anticancer therapy.

\section{Materials and Methods}

\subsection{Ethics Statement}

All procedures involving rodents were conducted in accordance with the National Institutes of Health regulations concerning the use and care of experimental animals and approved by the Universidad Central del Caribe Institutional Animal Care and Use Committee. All efforts were made to minimize suffering. In all surgical experiments, animals were anesthetized with isoflurane $(4 \%$ for induction and $1.75 \%$ for maintenance) using a Matrix Quanti-flex VMC Anesthesia Machine for small animals (Midmark Corporation, Dayton, OH, USA). The animals were sacrificed for brain tissue and blood analysis after experiments.

\subsection{Glioma Cell Culture}

The GL261 glioma cell line derived from C57BL/6 mice was obtained from the NCI (Frederick, MD, USA). All cells were cultured in Dulbecco's Modified Eagle's Medium (DMEM) supplemented with $10 \%$ fetal calf serum, $0.2 \mathrm{mM}$ glutamine, and antibiotics ( $50 \mathrm{U} / \mathrm{mL}$ penicillin, $50 \mu \mathrm{G} / \mathrm{mL}$ streptomycin) and maintained in a humidified atmosphere of $\mathrm{CO}_{2} /$ air $(5 \% / 95 \%)$ at $37{ }^{\circ} \mathrm{C}$. The medium was exchanged with fresh culture medium every 2-3 days.

\subsection{Intracranial Implantation of Glioma Cells}

All surgery was performed under isoflurane anesthesia, and all efforts were made to minimize suffering. GL261 glioma cells were implanted into the right cerebral hemisphere of 12-16-week-old C57BL/6 mice. Implantation was performed according to the protocol that we described earlier [26]. Briefly, mice were anesthetized with isoflurane, and a midline incision was made on the scalp. At stereotaxic coordinates of bregma, $2 \mathrm{~mm}$ lateral, $1 \mathrm{~mm}$ caudal, and $3 \mathrm{~mm}$ ventral, a small burr hole $\left(0.5 \mathrm{~mm}\right.$ diameter) was drilled into the skull. One microliter of cell suspension $\left(2 \times 10^{4} \mathrm{cells} / \mu \mathrm{L}\right.$ in phosphate buffer solution (PBS)) was delivered at a depth of $3 \mathrm{~mm}$ over $2 \mathrm{~min}$. Sixteen days following injection, the animals were anesthetized with pentobarbital $(50 \mathrm{mg} / \mathrm{kg})$ and transcardially perfused with PBS followed by $4 \%$ paraformaldehyde (PFA). The brains were removed and post-fixed in $4 \%$ PFA/PBS for $24 \mathrm{~h}$ at $4{ }^{\circ} \mathrm{C}$, followed by $0.15 \mathrm{M}, 0.5 \mathrm{M}$, and $0.8 \mathrm{M}$ sucrose at $4{ }^{\circ} \mathrm{C}$ until fully dehydrated. The brains were then frozen and embedded in Cryo-M-Bed embedding compound (Bright Instrument, Huntingdon, UK) and cut using a Vibratome UltraPro 5000 cryostat (American Instrument, Haverhill, MA, USA).

\subsection{Percoll Purification of Blood Cells from Tissue Samples for Membrane Fraction Isolation}

To study $A \beta$ distribution inside tumor cells, we first eliminated blood cells from the tumor tissue sample using the Percoll purification method. Tumors and healthy cortex from the contralateral hemisphere were removed from the mouse brains, minced into 1-2-mm pieces with a razor blade, 
and enzymatically homogenized using a collagenase/hyaluronidase in DMEM (cat. \#07912, Stemcell Technologies, WA, USA). Blood cells were separated from the homogenized tissue using Percoll (Sigma-Aldrich, St. Louis, MO, USA) gradients of 30\% and 70\%. Following this procedure the tissue fraction free from blood cells was collected from the top of the $70 \%$ Percoll level and used for further analysis.

\subsection{Isolation of Membrane and Cytoplasmic Proteins}

A homogenized cell suspension was resuspended and sonicated in $20 \mathrm{mM}$ Tris buffer containing $1 \mathrm{mM}$ ethylenedinitrilotetraacetic acid (EDTA), $1 \mathrm{mM} \beta$-mercaptoethanol, and $5 \%$ glycerin, $\mathrm{pH} 8.5$ with $\mathrm{HCl}, 1 \mu \mathrm{M} \mathrm{Na}_{3} \mathrm{VO}_{4}, 0.5 \mathrm{mM}$ phenylmethylsulfonyl fluoride (PMSF), and $10 \mathrm{mM}$ dithiothreitol (DTT). After centrifugation the supernatant was collected and used for further investigations as the cytoplasmic protein fraction. The pellet containing the membranes and the membrane proteins was lysed, and clarified cell lysate was used as the membrane protein fraction.

\subsection{Enzyme-Linked Immunosorbent Assay (ELISA) Measurements}

A specialized, ready-to-use, mouse-specific, solid-phase sandwich ELISA kit (cat. \#KMB3481; Invitrogen, Thermo Fisher Scientific, Waltham, MA, USA) was used for direct measurement of the amount of $A \beta 40$ peptide in the brains of experimental animals in accordance with the manufacturer's documentation. Briefly, the brain samples were homogenized mechanically, and $100 \mathrm{mg}$ of homogenate was then lysed in guanidine solution ( $5 \mathrm{M}$ guanidine $\mathrm{HCl}, 50 \mathrm{mM}$ Tris $\mathrm{HCl}, \mathrm{pH}$ 8.0). In other experiments, the lysate (normalized to total protein content) from membrane and cytoplasmic fractions (see above) were used. A monoclonal antibody against the $\mathrm{NH}_{2}$-terminus of mouse $\mathrm{A} \beta 40$ peptide was coated onto the wells of the microtiter strips provided in the kit. Samples, including standards of known A $\beta 40$ content for calibration purposes as well as experimental specimens, were pipetted into the wells. After washing, the rabbit antibody specific to the $\mathrm{COOH}$-terminus of $\mathrm{A} \beta 40$ was added and detected with horseradish peroxidase-labeled anti-rabbit antibody. The optical density values at $450 \mathrm{~nm}$ were determined using a Wallac 1420 Victor 2 Microplate Reader (PerkinElmer Inc., Waltham, MA, USA). The calculated mean reading from the healthy hemisphere (normalized cytoplasmic fraction) was defined as $100 \%$, while other readings were presented as the percentage of this value.

\subsection{Immunohistochemistry and Confocal Microscopy}

Immunostaining was performed using a protocol previously established in our laboratory [22,62]. Frozen $30-\mu \mathrm{m}$ sections were generated from brain cortex containing the tumor(s). The sections were blocked with $5 \%$ normal goat serum $/ 5 \%$ normal horse serum (Vector Laboratories, Burlingame, CA, USA) in $0.10 \mathrm{M}$ phosphate buffer solution (PBS: $\mathrm{NaCl}, 137 \mathrm{mM} ; \mathrm{KCl}, 2.70 \mathrm{mM} ; \mathrm{Na}_{2} \mathrm{HPO}_{4}$, $10.14 \mathrm{mM} ; \mathrm{KH}_{2} \mathrm{PO}_{4}, 1.77 \mathrm{mM}$ ) containing $0.3 \%$ Triton $\mathrm{X}-100$ and $0.05 \%$ phenylhydrazine for $60 \mathrm{~min}$ for permeabilization and then processed separately using two different antibodies against $\mathrm{A} \beta$. For that purpose, slices were incubated with a rabbit polyclonal antibody to A $\beta$ (Abcam, Cambridge, MA, USA, cat. \#ab2539) diluted 1:400 in 0.03\% Triton X-100, 1\% dimethyl sulfoxide (DMSO), $2 \%$ bovine serum albumin (BSA), 5\% normal horse serum, and 5\% normal goat serum in $0.1 \mathrm{M}$ PBS. Anti-GFAP-Cy3 (1:200) was added, and the slice left overnight at $4{ }^{\circ} \mathrm{C}$. After three washes with permeabilization solution for $10 \mathrm{~min}$, the secondary antibodies (fluorescein-labeled goat anti-rabbit IgG) were added at a dilution of 1:200 with shaking for $2 \mathrm{~h}$ at room temperature and protected from light. The slices were then washed three times with PBS for $10 \mathrm{~min}$ and once with distilled water before being transferred onto a glass slide containing Fluoroshield mounting medium (Sigma-Aldrich, St. Louis, MO, USA, cat. \#F6057) with DAPI. Negative controls were routinely performed by removal of primary antibody in each staining experiment to validate the immunohistochemical staining quality and results.

For thioflavin (Th) staining we used: (1) ThT staining, in which mice were injected IP with $10 \mu \mathrm{L} / \mathrm{g}$ of $3 \mathrm{mM}$ solution of ThT in PBS. After $5 \mathrm{~min}$, the animals were euthanized, and the brains were harvested and kept in fixative without light. (2) ThS staining, in which brain slices ( $30 \mu \mathrm{m})$ containing 
tumors were allowed to completely air dry prior to staining, then stained with a drop of $3 \mathrm{mM}$ ThS in PBS (previously filtered through a $0.2-\mu \mathrm{m}$ filter) for $5 \mathrm{~min}$, then washed twice with distilled water and dried again. The coverslip was mounted with a drop of Vaseline on the slice. DAPI and Cy3 excitation/emission filters were used to visualize ThT and ThS fluorescence, respectively.

Images were acquired using an Olympus Fluoview FV1000 scanning inverted confocal microscope system equipped with a $20 \times, 40 \times$, or $60 \times / 1.43$ oil objective (Olympus, Melville, NY, USA). The images were analyzed using ImageJ software (http://imagej.nih.gov/ij) with the Open Microscopy Environment Bio-Formats library and plugin, allowing for the opening of Olympus files (http://www.openmicroscopy. org/site/support/bio-formats5.4/). The data were evaluated using custom colorization.

\subsection{Statistics and Measurements}

Using GraphPad Prism 7.03 (GraphPad Software, Inc., La Jolla, CA, USA) for calculations, an unpaired $t$-test was employed to estimate statistical differences. Values were determined to be significantly different if the two-tailed $p$-value was $<0.05$.

\section{Conclusions}

- Aggregated amyloid is present inside glioma tumor borders;

- $\mathrm{A} \beta$ peptide immunofluorescence is present in glioma tumors, marking glioma cells and nearby ruptured blood vessels.

Supplementary Materials: Supplementary materials can be found at http://www.mdpi.com/1422-0067/20/10/ 2482/s1.

Author Contributions: Conceptualization, methodology, original draft preparation, review and editing, and formal analysis were performed by M.Y.I. and L.Y.K.; experimental investigation, formal analysis, visualization, data curation, and review and editing were performed by L.Y.K., A.Z.-S., A.D.-G., J.-O.-R., and Y.V.K.

Funding: This research was supported by NIH grants SC1GM122691 to L.Y.K. and SC2GM111149 to M.Y.I. The funding sources had no role in study design; data collection, analysis, or interpretation; or the decision to submit this article.

Acknowledgments: We want to thank personnel of Animal Resources Center in Universidad Central del Caribe for their kind help.

Conflicts of Interest: The authors declare that they have no conflicts of interest. The funders had no role in the design of the study; in the collection, analyses, or interpretation of data; in the writing of the manuscript; or in the decision to publish the results.

$\begin{array}{ll}\text { Abbreviations } \\ \text { ELISA } & \text { enzyme-linked immunosorbent assay } \\ \text { ThS } & \text { Thioflavin S } \\ \text { ThT } & \text { Thioflavin T } \\ \text { PMSF } & \text { Phenylmethylsulfonyl fluoride } \\ \text { DTT } & \text { Dithiothreitol } \\ \text { DMEM } & \text { Dulbecco's Modified Eagle's Medium } \\ \text { A } \beta & \text { Amyloid beta peptide }\end{array}$

\section{References}

1. Guerreiro, R.; Bras, J. The age factor in Alzheimer's disease. Genome Med. 2015, 7, 106. [CrossRef] [PubMed]

2. Young, J.S.; Chmura, S.J.; Wainwright, D.A.; Yamini, B.; Peters, K.B.; Lukas, R.V. Management of glioblastoma in elderly patients. J. Neurol. Sci. 2017, 380, 250-255. [CrossRef]

3. Ou, S.M.; Lee, Y.J.; Hu, Y.W.; Liu, C.J.; Chen, T.J.; Fuh, J.L.; Wang, S.J. Does Alzheimer's disease protect against cancers? A nationwide population-based study. Neuroepidemiology 2013, 40, 42-49. [CrossRef] [PubMed] 
4. Musicco, M.; Adorni, F.; Di Santo, S.; Prinelli, F.; Pettenati, C.; Caltagirone, C.; Palmer, K.; Russo, A. Inverse occurrence of cancer and Alzheimer disease: A population-based incidence study. Neurology 2013, 81, 322-328. [CrossRef]

5. Yarchoan, M.; James, B.D.; Shah, R.C.; Arvanitakis, Z.; Wilson, R.S.; Schneider, J.; Bennett, D.A.; Arnold, S.E. Association of Cancer History with Alzheimer's Disease Dementia and Neuropathology. J. Alzheimers Dis. 2017, 56, 699-706. [CrossRef]

6. Driver, J.A.; Beiser, A.; Au, R.; Kreger, B.E.; Splansky, G.L.; Kurth, T.; Kiel, D.P.; Lu, K.P.; Seshadri, S.; Wolf, P.A. Inverse association between cancer and Alzheimer's disease: Results from the Framingham Heart Study. BMJ 2012, 344, e1442. [CrossRef] [PubMed]

7. Lehrer, S. Glioblastoma and dementia may share a common cause. Med. Hypotheses 2010, 75, 67-68. [CrossRef]

8. Lehrer, S. Glioma and Alzheimer's Disease. J. Alzheimers Dis. Rep. 2018, 2, 213-218. [CrossRef]

9. Behrens, M.I.; Lendon, C.; Roe, C.M. A common biological mechanism in cancer and Alzheimer's disease? Curr. Alzheimer Res. 2009, 6, 196-204. [CrossRef]

10. Sánchez-Valle, J.; Tejero, H.; Ibáñez, K.; Portero, J.L.; Krallinger, M.; Al-Shahrour, F.; Tabarés-Seisdedos, R.; Baudot, A.; Valencia, A. A molecular hypothesis to explain direct and inverse co-morbidities between Alzheimer's Disease, Glioblastoma and Lung cancer. Sci. Rep. 2017, 7, 4474. [CrossRef]

11. Hansel, D.E.; Rahman, A.; Wehner, S.; Herzog, V.; Yeo, C.J.; Maitra, A. Increased expression and processing of the Alzheimer amyloid precursor protein in pancreatic cancer may influence cellular proliferation. Cancer Res. 2003, 63, 7032-7037. [PubMed]

12. Tsang, J.Y.S.; Lee, M.A.; Ni, Y.B.; Chan, S.K.; Cheung, S.Y.; Chan, W.W.; Lau, K.F.; Tse, G.M.K. Amyloid Precursor Protein Is Associated with Aggressive Behavior in Nonluminal Breast Cancers. Oncologist 2018, 23, 1273-1281. [CrossRef] [PubMed]

13. Tsang, J.Y.S.; Lee, M.A.; Chan, T.H.; Li, J.; Ni, Y.B.; Shao, Y.; Chan, S.K.; Cheungc, S.Y.; Lau, K.F.; Tse, G.M.K. Proteolytic cleavage of amyloid precursor protein by ADAM10 mediates proliferation and migration in breast cancer. EBioMedicine 2018, 38, 89-99. [CrossRef] [PubMed]

14. Jin, W.S.; Bu, X.L.; Liu, Y.H.; Shen, L.L.; Zhuang, Z.Q.; Jiao, S.S.; Zhu, C.; Wang, Q.H.; Zhou, H.D.; Zhang, T.; et al. Plasma Amyloid-Beta Levels in Patients with Different Types of Cancer. Neurotox. Res. 2017, 31, 283-288. [CrossRef] [PubMed]

15. Morato, E.; Mayor, F., Jr. Production of the Alzheimer's beta-amyloid peptide by C6 glioma cells. FEBS Lett. 1993, 336, 275-278. [CrossRef]

16. Murphy, S.F.; Banasiak, M.; Yee, G.-T.; Wotoczek-Obadia, M.; Tran, Y.; Prak, A.; Albright, R.; Mullan, M.; Paris, D.; Brem, S. A synthetic fragment of beta-amyloid peptide suppresses glioma proliferation, angiogenesis, and invasiveness in vivo and in vitro. Neuro-Oncol. 2010, 12, iv5. [CrossRef]

17. Paris, D. Modulation of Angiogenesis by a-Beta Peptide Fragments. Patent US20080031954A1, 7 February 2005.

18. Paris, D.; Gan ey, N.; Banasiak, M.; Laporte, V.; Patel, N.; Mullan, M.; Murphy, S.F.; Yee, G.T.; Bachmeier, C.; Ganey, C.; et al. Impaired orthotopic glioma growth and vascularization in transgenic mouse models of Alzheimer's disease. J. Neurosci. 2010, 30, 11251-11258. [CrossRef]

19. Inyushin, M.Y.; Sanabria, P.; Rojas, L.; Kucheryavykh, Y.; Kucheryavykh, L. A $\beta$ Peptide Originated from Platelets Promises New Strategy in Anti-Alzheimer's Drug Development. Biomed. Res. Int. 2017, 2017, 3948360. [CrossRef]

20. Inyushin, M.; Zayas-Santiago, A.; Rojas, L.; Kucheryavykh, Y.; Kucheryavykh, L. Platelet-generated amyloid beta peptides in Alzheimer's disease and glaucoma. Histol. Histopathol. 2019, 18111. [CrossRef]

21. Kucheryavykh, L.Y.; Dávila-Rodríguez, J.; Rivera-Aponte, D.E.; Zueva, L.V.; Washington, A.V.; Sanabria, P.; Inyushin, M.Y. Platelets are responsible for the accumulation of $\beta$-amyloid in blood clots inside and around blood vessels in mouse brain after thrombosis. Brain Res. Bull. 2017, 128, 98-105. [CrossRef]

22. Kucheryavykh, L.Y.; Kucheryavykh, Y.V.; Washington, A.V.; Inyushin, M.Y. Amyloid Beta Peptide Is Released during Thrombosis in the Skin. Int. J. Mol. Sci. 2018, 19, 1705. [CrossRef]

23. Jurasz, P.; Alonso-Escolano, D.; Radomski, M.W. Platelet-cancer interactions: Mechanisms and pharmacology of tumour cell-induced platelet aggregation. Br. J. Pharm. 2004, 143, 819-826. [CrossRef] [PubMed]

24. Goubran, H.A.; Burnouf, T.; Radosevic, M.; El-Ekiaby, M. The platelet-cancer loop. Eur. J. Intern. Med. 2013, 24, 393-400. [CrossRef] 
25. Hermanson, M.; Funa, K.; Hartman, M.; Claesson-Welsh, L.; Heldin, C.H.; Westermark, B.; Nistér, M. Platelet-derived growth factor and its receptors in human glioma tissue: Expression of messenger RNA and protein suggests the presence of autocrine and paracrine loops. Cancer Res. 1992, 52, 3213-3219.

26. Kucheryavykh, L.Y.; Kucheryavykh, Y.V.; Rolón-Reyes, K.; Skatchkov, S.N.; Eaton, M.J.; Cubano, L.A.; Inyushin, M.Y. Visualization of implanted GL261 glioma cells in living mouse brain slices using fluorescent 4-(4-(dimethylamino)-styryl)- $N$-methylpyridinium iodide (ASP+). Biotechniques 2012. [CrossRef] [PubMed]

27. Rolón-Reyes, K.; Kucheryavykh, Y.V.; Cubano, L.A.; Inyushin, M.; Skatchkov, S.N.; Eaton, M.J.; Harrison, J.K.; Kucheryavykh, L.Y. Microglia Activate Migration of Glioma Cells through a Pyk2 Intracellular Pathway. PLoS ONE 2015, 10, e0131059. [CrossRef] [PubMed]

28. Dubois, L.G.; Campanati, L.; Righy, C.; D’Andrea-Meira, I.; Spohr, T.C.; Porto-Carreiro, I.; Pereira, C.M.; Balça-Silva, J.; Kahn, S.A.; DosSantos, M.F.; et al. Gliomas and the vascular fragility of the blood brain barrier. Front. Cell Neurosci. 2014, 8, 418. [CrossRef] [PubMed]

29. Lan, J.; Liu, J.; Zhao, Z.; Xue, R.; Zhang, N.; Zhang, P.; Zhao, P.; Zheng, F.; Sun, X. The peripheral blood of A $\beta$ binding RBC as a biomarker for diagnosis of Alzheimer's disease. Age Ageing 2015, 44, 458-464. [CrossRef]

30. Mohanty, J.G.; Eckley, D.M.; Williamson, J.D.; Launer, L.J.; Rifkind, J.M. Do red blood cell- $\beta$-amyloid interactions alter oxygen delivery in Alzheimer's disease? Adv. Exp. Med. Biol. 2008, 614, $29-35$.

31. Kelényi, G. Thioflavin S fluorescent and Congo red anisotropic stainings in the histologic demonstration of amyloid. Acta Neuropathol. 1967, 7, 336-348. [CrossRef]

32. Biancalana, M.; Koide, S. Molecular mechanism of Thioflavin-T binding to amyloid fibrils. Biochim. Biophys. Acta 2010, 1804, 1405-1412. [CrossRef]

33. Wu, Y.; Du, S.; Johnson, J.L.; Tung, H.Y.; Landers, C.T.; Liu, Y.; Seman, B.G.; Wheeler, R.T.; Costa-Mattioli, M.; Kheradmand, F.; et al. Microglia and amyloid precursor protein coordinate control of transient Candida cerebritis with memory deficits. Nat. Commun. 2019, 10, 58. [CrossRef] [PubMed]

34. Brody, A.H.; Strittmatter, S.M. Synaptotoxic Signaling by Amyloid Beta Oligomers in Alzheimer's Disease Through Prion Protein and mGluR5. Adv. Pharm. 2018, 82, 293-323. [CrossRef]

35. Salazar, S.V.; Cox, T.O.; Lee, S.; Brody, A.H.; Chyung, A.S.; Haas, L.T.; Strittmatter, S.M. Alzheimer's Disease Risk Factor Pyk2 Mediates Amyloid- $\beta$-Induced Synaptic Dysfunction and Loss. J. Neurosci. 2019, 39, 758-772. [CrossRef] [PubMed]

36. Lipinski, C.A.; Tran, N.L.; Menashi, E.; Rohl, C.; Kloss, J.; Bay, R.C.; Berens, M.E.; Loftus, J.C. The tyrosine kinase pyk2 promotes migration and invasion of glioma cells. Neoplasia 2005, 7, 435-445. [CrossRef]

37. Fan, Q.W.; Weiss, W.A. Targeting the RTK-PI3K-mTOR axis in malignant glioma: Overcoming resistance. Curr. Top. Microbiol. Immunol. 2010, 347, 279-296. [CrossRef]

38. Zhao, H.F.; Wang, J.; Shao, W.; Wu, C.P.; Chen, Z.P.; To, S.T.; Li, W.P. Recent advances in the use of PI3K inhibitors for glioblastoma multiforme: Current preclinical and clinical development. Mol. Cancer 2017, 16, 100. [CrossRef] [PubMed]

39. Klippel, A.; Reinhard, C.; Kavanaugh, W.M.; Apell, G.; Escobedo, M.A.; Williams, L.T. Membrane localization of phosphatidylinositol 3-kinase is sufficient to activate multiple signal-transducing kinase pathways. Mol. Cell. Biol. 1996, 16, 4117-4127. [CrossRef]

40. Gao, X.; Lowry, P.R.; Zhou, X.; Depry, C.; Wei, Z.; Wong, G.W.; Zhang, J. PI3K/Akt signaling requires spatial compartmentalization in plasma membrane microdomains. Proc. Natl. Acad. Sci. USA 2011, 108, 14509-14514. [CrossRef]

41. Chen, T.J.; Wang, D.C.; Chen, S.S. Amyloid-beta interrupts the PI3K-Akt-mTOR signaling pathway that could be involved in brain-derived neurotrophic factor-induced Arc expression in rat cortical neurons. J. Neurosci. Res. 2009, 87, 2297-2307. [CrossRef]

42. Mruthinti, S.; Hill, W.D.; Swamy-Mruthinti, S.; Buccafusco, J.J. Relationship between the induction of RAGE cell-surface antigen and the expression of amyloid binding sites. J. Mol. Neurosci. 2003, 20, $223-232$. [CrossRef]

43. Deane, R.; Du Yan, S.; Submamaryan, R.K.; LaRue, B.; Jovanovic, S.; Hogg, E.; Welch, D.; Manness, L.; Lin, C.; $\mathrm{Yu}, \mathrm{J}$.; et al. RAGE mediates amyloid-beta peptide transport across the blood-brain barrier and accumulation in brain. Nat. Med. 2003, 9, 907-913. [CrossRef] [PubMed]

44. Logsdon, C.D.; Fuentes, M.K.; Huang, E.H.; Arumugam, T. RAGE and RAGE ligands in cancer. Curr. Mol. Med. 2007, 7, 777-789. [CrossRef] [PubMed] 
45. Verkhratsky, A.; Olabarria, M.; Noristani, H.N.; Yeh, C.-Y.; Rodriguez, J.J. Astrocytes in Alzheimer's Disease. Neurotherapeutics 2010, 7, 399-412. [CrossRef] [PubMed]

46. Veeraraghavalu, K.; Zhang, C.; Zhang, X.; Tanzi, R.E.; Sisodia, S.S. Age-dependent non-cell-autonomous deposition of amyloid from synthesis of $\beta$-amyloid by cells other than excitatory neurons. J. Neurosci. 2014, 34, 3668-3673. [CrossRef]

47. Frost, G.R.; Li, Y.M. The role of astrocytes in amyloid production and Alzheimer's disease. Open Biol. 2017, 7, 170228. [CrossRef] [PubMed]

48. Teich, A.F.; Patel, M.; Arancio, O. A reliable way to detect endogenous murine $\beta$-amyloid. PLoS ONE 2013, 8, e55647. [CrossRef]

49. Okereke, O.I.; Xia, W.; Irizarry, M.C.; Sun, X.; Qiu, W.Q.; Fagan, A.M.; Mehta, P.D.; Hyman, B.T.; Selkoe, D.J.; Grodstein, F. Performance characteristics of plasma amyloid-beta 40 and 42 assays. J. Alzheimers Dis. 2009, 16, 277-285. [CrossRef]

50. Aluise, C.D.; Sowell, R.A.; Butterfield, D.A. Peptides and proteins in plasma and cerebrospinal fluid as biomarkers for the prediction, diagnosis, and monitoring of therapeutic efficacy of Alzheimer's disease. Biochim. Biophys. Acta 2008, 1782, 549-558. [CrossRef]

51. Stewart, K.L.; Radford, S.E. Amyloid plaques beyond A $\beta$ : A survey of the diverse modulators of amyloid aggregation. Biophys. Rev. 2017, 9, 405-419. [CrossRef]

52. Ganesan, A.; Debulpaep, M.; Wilkinson, H.; Van Durme, J.; De Baets, G.; Jonckheere, W.; Ramakers, M.; Ivarsson, Y.; Zimmermann, P.; Van Eldere, J.; et al. Selectivity of aggregation-determining interactions. J. Mol. Biol. 2015, 427, 236-247. [CrossRef]

53. Bolognesi, B.; Tartaglia, G.G. Physicochemical principles of protein aggregation. Prog. Mol. Biol. Transl. Sci. 2013, 117, 53-72. [CrossRef] [PubMed]

54. Valenta, L.J.; Michel-Bechet, M.; Mattson, J.C.; Singer, F.R. Microfollicular thyroid carcinoma with amyloid rich stroma, resembling the medullary carcinoma of the thyroid (MCT). Cancer 1977, 39, 1573-1586. [CrossRef]

55. Khan, I.S.; Loh, K.S.; Petersson, F. Amyloid and hyaline globules in undifferentiated nasopharyngeal carcinoma. Ann. Diagn. Pathol. 2019, 40,1-6. [CrossRef] [PubMed]

56. Franklin, C.D.; Martin, M.V.; Clark, A.; Smith, C.J.; Hindle, M.O. An investigation into the origin and nature of 'amyloid' in a calcifying epithelial odontogenic tumour. J. Oral Pathol. 1981, 10, 417-429. [CrossRef] [PubMed]

57. Delaney, M.A.; Singh, K.; Murphy, C.L.; Solomon, A.; Nel, S.; Boy, S.C. Immunohistochemical and biochemical evidence of ameloblastic origin of amyloid-producing odontogenic tumors in cats. Vet. Pathol. 2013, 50, 238-242. [CrossRef] [PubMed]

58. Hirayama, K.; Endoh, C.; Kagawa, Y.; Ohmachi, T.; Yamagami, T.; Nomura, K.; Matsuda, K.; Okamoto, M.; Taniyama, H. Amyloid-Producing Odontogenic Tumors of the Facial Skin in Three Cats. Vet. Pathol. 2017, 54, 218-221. [CrossRef]

59. Silverman, J.F.; Dabbs, D.J.; Norris, H.T.; Pories, W.J.; Legier, J.; Kay, S. Localized primary (AL) amyloid tumor of the breast. Cytologic, histologic, immunocytochemical and ultrastructural observations. Am. J. Surg. Pathol. 1986, 10, 539-545. [CrossRef] [PubMed]

60. Mori, M.; Kotani, H.; Sawaki, M.; Hattori, M.; Yoshimura, A.; Gondo, N.; Adachi, Y.; Kataoka, A.; Sugino, K.; Horisawa, N.; et al. Amyloid tumor of the breast. Surg. Case Rep. 2019, 5, 31. [CrossRef]

61. Rosenzweig, M.; Landau, H. Light chain (AL) amyloidosis: Update on diagnosis and management. J. Hematol. Oncol. 2011, 4, 47. [CrossRef]

62. Zayas-Santiago, A.; Ríos, D.S.; Zueva, L.V.; Inyushin, M.Y. Localization of $\alpha$ A-Crystallin in Rat Retinal Müller Glial Cells and Photoreceptors. Microsc. Microanal. 2018, 24, 545-552. [CrossRef] [PubMed]

(C) 2019 by the authors. Licensee MDPI, Basel, Switzerland. This article is an open access article distributed under the terms and conditions of the Creative Commons Attribution (CC BY) license (http://creativecommons.org/licenses/by/4.0/). 